\title{
Report Submitter
}

National Cancer Institute

\section{Source}

National Cancer Institute. Report Submitter. NCI Thesaurus. Code C93447.

The individual who submits a report. 